\title{
FIRST REPORT OF COCHLODINIUM POLYKRIKOIDES (DINOPHYCEAE), A HARMFUL ALGAL BLOOM (HAB) SPECIES IN THE COASTAL WATERS OF PENINSULAR MALAYSIA
}

\author{
Siti NorRohaida Harun ${ }^{1}$, Normawaty Mohammad-Noor ${ }^{1,2, *}$, Zuhairi Ahmad ${ }^{1,2}$, Kua \\ Beng Chu ${ }^{3}$, Shahbudin Saad ${ }^{1,2}$, Nor Salamah Mohamad Hidayat ${ }^{1}$ \& Yukinori Mu- \\ $\mathbf{k a i}^{1,2}$
}

${ }^{1}$ Department of Marine Science, Kulliyyah of Science, International Islamic University Malaysia, Jalan Sultan Ahmad Shah, Bandar Indera Mahkota, Kuantan, Pahang, Malaysia

${ }^{2}$ Institute of Oceanogrpahy and Maritime Studies, International Islamic University Malaysia, Kg. Cherok Paloh, Kuantan, Pahang, Malaysia

${ }^{3}$ National Fish Health Research Centre, Fisheries Research Institute, Department of Fisheries Malaysia, Batu Maung, Penang, Malaysia

*Corresponding author: normahwaty@iium.edu.my

\begin{abstract}
Cochlodinium polykrikoides is known as fish killer. In Malaysia this species has been recorded in Kota Kinabalu, Sabah, Borneo Island. To date, C. polykrikoides has not been recorded in Peninsular Malaysia. This study aims to identify the presence of C. polykrikoides in Peninsular Malaysia particularly in Tanjung Piandang, Kuala Kurau and Kuala Gula located in Perak coastal waters and Straits of Tebrau, Johor. Samplings were carried out for three times at each sampling station. Ten litre of water samples were collected for cell enumeration and identification. For identification, plankton samples were identified under light microscope. Nutrients i.e. nitrate, phosphate and ammonia were determined and physico-chemical parameters ( $\mathrm{pH}$, temperature, salinity) were also recorded in-situ. Species was identified as C. polykrikoides based on their morphological characteristics. Result showed that $C$. polykrikoides was presence in high abundance in both Perak coastal waters and Straits of Tebrau at concentration of $2.5 \times 10^{3}$ cells/L and $4.7 \times 10^{3}$ cells/L, respectively. No significant difference was found between cell abundance at these two locations. $\mathrm{pH}$, salinities and temperatures recorded at both locations range between $7.68-7.80,27.23-28.03 \mathrm{psu}$ and $29.32-30.90{ }^{\circ} \mathrm{C}$, respectively. There was no significant difference in the physico-chemical parameters ( $>0.05$ ) between stations. Regression analysis showed no correlations were between cell abundance and physico-chemical parameters and nutrients. The presence of $C$. polykrikoides in the coastal waters of Peninsular Malaysia indicates that possible mitigation needs to be given attention by the relevant agencies as this species can bring negative impact to aquaculture industry.
\end{abstract}

\begin{abstract}
ABSTRAK Cochlodinium polykrikoides di kenali sebagai 'fish-killer'. Di Malaysia, spesis ini telah direkodkan di Kota Kinabalu, Sabah, Kepulauan Borneo. Setakat ini, C. polykrikoides tidak direkodkan hadir di perairan Semenanjung Malaysia. Tujuan kajian ini dijalankan adalah untuk mengenapasti kehadiran C. polykrikoides di Semenanjung Malaysia terutamanya di Tanjung Piandang, Kuala Kurau dan Kuala Gula, di perairan pesisir pantai Perak dan Selat Tebrau, Johor. Persampelan dijalankan sebanyak tiga kali di setiap stesen. Sepuluh liter sampel air laut dikutip untuk tujuan penentuan kelimpahan sel. Untuk pengecaman, fitopalnkton dikenalpasti menggunakan mikroskop cahaya. Nutrien seperti nitrat, fosfat dan ammonia di tentukan dan parameter fiziko-kimia direkodkan di tempat kajian. Berdasarkan ciri - ciri morfologi, spesis ini telah dikenalpasti sebagai C. polykrikoides. Keputusan pengiraan menunjukkan C. polykrikoides hadir dalam jumlah yang tinggi di kedua-dua Perak dan Selat Tebrau dengan kepekatan sel $2.5 \times 10^{3} \mathrm{sel} / \mathrm{L}$ dan $4.7 \times 10^{3} \mathrm{sel} / \mathrm{L}$, masing-masing. $\mathrm{pH}$, kemasinan dan suhu yang direkodkan di kedua-dua tempat adalah di dalam julat $7.68-7.80,27.23-28.03$ psu and $29.32-30.90{ }^{\circ} \mathrm{C}$, masing-masing. Tiada perbezaan bererti $(\mathrm{P}>0.05)$ ditemui diantara parameter fiziko-kimia dan stesen. Analisis regrasi menunjukkan tiada korelasi positif ditemui di antara kepekatan sel dan parameter fiziko-kimia dan nutrien. Kehadiaran C. polykrikoides di peraiaran Semenanjung Malaysia menunjukkan beberapa langkah pengawalan perlu diambil kira oleh agensi berkaitan memandangkan spesis ini boleh mendatangkan kesan negatif kepada industri akuakultur.
\end{abstract}

(Keywords: Cochlodinium polykrikoides; fish-cage; Harmful Algal Bloom; Malaysia; Strait of Malacca)

\section{INTRODUCTION}

The first case of harmful algal bloom (HAB) was reported in Kota Kinabalu, Sabah, East Coast of
Peninsular Malaysia in 1976 and the causative organism was identified as Pyrodinium bahamense var. compressum [1]. Since then, many HAB cases have been reported in the coastal areas of Malaysia 
including the Peninsular Malaysia.

C. polykrikodes is a catenated, athecate, ichthytoxic dinoflagellate species and have been recorded to occur in many countries including Japan [2], the Philippines [3], Korea (e.g. [4], China [5], Europe, America (e.g. [6] etc. The occurrence of the species appears to be expending globally as new areas were reported annually. This species is considered as harmful blooming species as it cause mortalities of both wild and farmed fish [7]. In Malaysia, $C$. polykrikoides was first reported in Kota Kinabalu, Sabah in 2005 [8]. During the event, caged fish mortality was reported. Consequently in 2007, the blooms of $C$. polykriokides continued to dominate the area and nutrients from heavy rainfall supports the occurrence of this species [9]. During these events the fishermen experiences a great loss. This indicates that blooms of Cochlodinium can cause severe impact towards aquaculture industry in Malaysia. To date there was no record on the occurrence of $C$. polykrikoides in Peninsular Malaysia. Therefore, the objective of this study was to determine the occurrence and distribution of $\mathrm{C}$. polykrikoides blooms in several places viz. Perak and Straits of Tebrau, in Peninsular Malaysia. During this study, phytoplankton blooms were reported in Perak coastal waters causing red discoloration of the water and coincided with mortality of cultured finfish. To support this study, physico-chemical parameters were recorded in-situ. Results of this study are important to create awareness among the fishermen and relevant agencies on the emerging problem of $\mathrm{HAB}$ cause by $C$. polykrikoides particularly in Peninsular Malaysia.

\section{MATERIALS AND METHODS}

Samples of phytoplankton were collected from Perak coastal area, West Coast of Peninsular Malaysia and Straits of Tebrau, located between Johor and Singapore (Figure 1). Samples from Perak coastal waters i.e. at Tanjung Piandang, Kuala Kurau and Kuala Gula were first collected on March 2013 which was approximately one week after the bloom was reported by Fisheries Department, Malaysia. Samples were collected at 9 stations from Perak coastal waters. These stations were located in 3 transects and these transects were located $1 \mathrm{~km}$ from the shore (Figure 1). The distance between stations was $10 \mathrm{~km}$ and between transects was $5 \mathrm{~km}$. In Straits of Tebrau, samples were collected from 5 stations situated along the straits. Both areas received influence from rivers nearby and a lot of fish cages were observed here. Samples were collected three times at each sampling area which were $15^{\text {th }}$ March 2013, $18^{\text {th }}$ June 2013 and $23^{\text {rd }}$ October for Perak and $4^{\text {th }}$ April 2013, $6^{\text {th }}$ July 2013 and $6^{\text {th }}$ October 2013 for Johor.

At each station, $10 \mathrm{~L}$ of phytoplankton samples were collected at $0.5 \mathrm{~m}$ below the sea surface by using Van Dorn water sampler and preserved immediately with Lugol's iodine. In the laboratory, these samples were concentrated into $50 \mathrm{~mL}$ [10]. Enumeration was done by counting the cells in $1 \mathrm{~mL}$ of sample using Sedgwick Rafter cell under light microscope at magnification of 100 times. Cell enumerations were performed twice for each sample and cell abundances in cells/L were determined as below:

$1 \mathrm{~mL}=\mathrm{x}$ cells

$50 \mathrm{~mL}=\mathrm{x}$ cells $\mathrm{x} 50 \mathrm{~mL}=\mathrm{x}$ cells $/ 50 \mathrm{~mL}=\mathrm{x}$ cells $/ 10 \mathrm{~L}$

In $1 \mathrm{~L}=(\mathrm{x}$ cells $/ 10 \mathrm{~L}) \times 1 \mathrm{~L}=\mathrm{x}$ cells $/ \mathrm{L}$

Nutrients such as nitrate, phosphate and ammonia were also determined using standard methods by Parson et al.[11]. Physico-chemical parameters such as temperature $\left({ }^{\circ} \mathrm{C}\right)$, salinity (psu), turbidity and $\mathrm{pH}$ were recorded using YSI 556 Multi-Probe System at the same depth where phytoplankton samples were collected. Statistical analysis such as oneway Analysis of Variance (ANOVA) was used to determine the significant difference of cell densities, physico-chemical parameters and nutrients between each station. Regression analysis was carried out to determine the relationship between cell abundance and physic-chemico parameters including nutrients. 


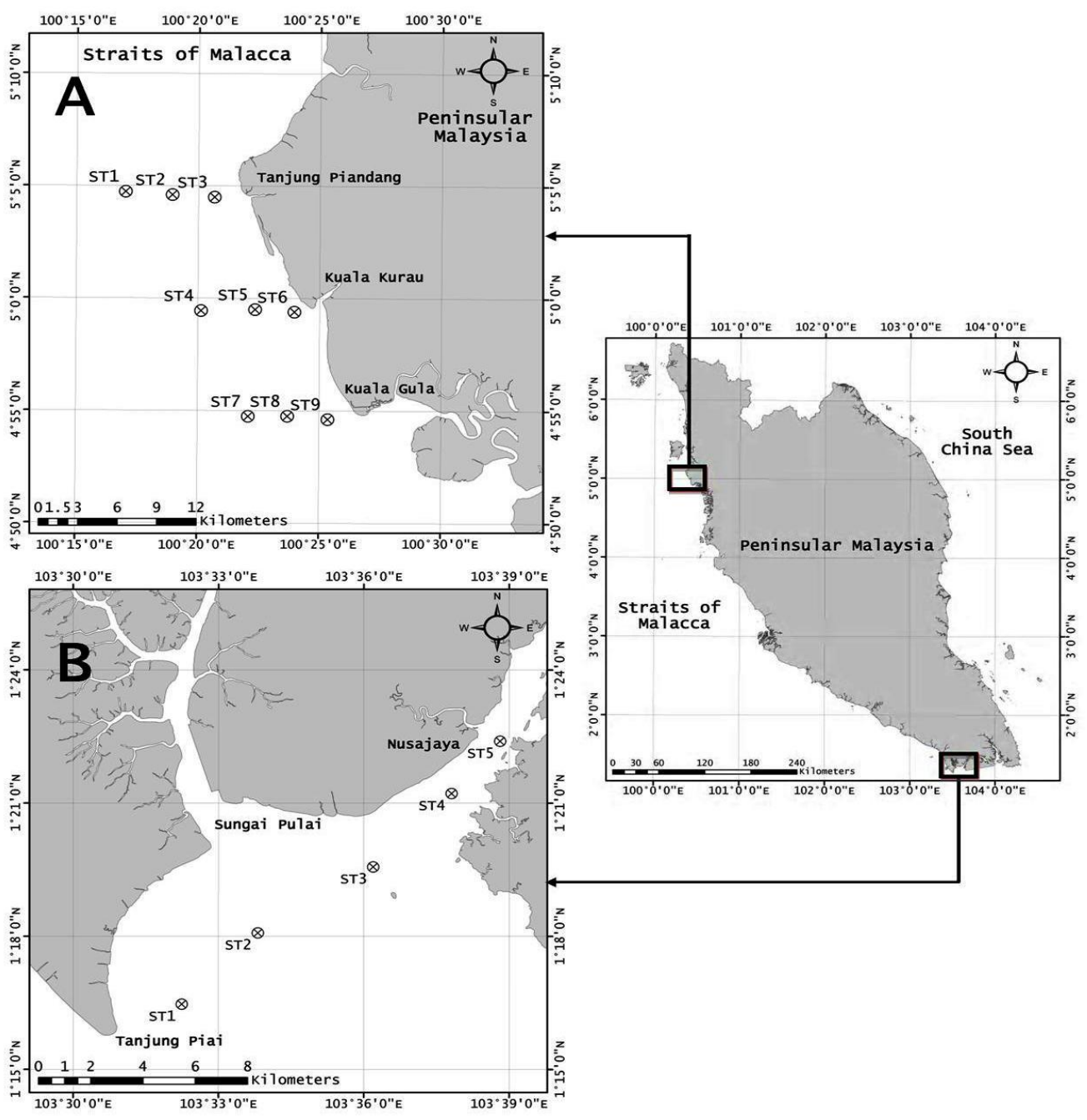

Figure 1. Map of Peninsular Malaysia showing A. Sampling site at Perak coastal water and B. Sampling sites at Straits of Tebrau.

\section{RESULTS AND DISCUSSION}

Species formed chain of 2-4 cells, $30-40 \mu \mathrm{m}$ in long and $20-24 \mu \mathrm{m}$ in wide, unarmored and slightly compressed dorsoventrally (Figure 2). Based on morphological characteristics, the species was identified as Cochlodinium polykrikoides (Figure 2). In Perak coastal water, C. polykrikoides abundance reached the cell density of $2.5 \times 10^{3}$ cells/L during the first sampling and 40 cells/L during second sampling (Figure 3). No cell was recorded during third sampling. Cochlodinium blooms in Perak were reported to occur more than a week before the first sampling was done. Samples of seawater taken during the events showed $C$. polykrikoides dominated the plankton (Figure 2).
In Straits of Tebrau, C. polykrikoides was found on second sampling with the highest cell density of 4.7 x $10^{3}$ cells/L at Station 2 (Figure 2). However, no C. polykrikoides was found on the first and third samplings.

Fish die due to C. polykrikoides blooms have been reported elsewhere including in Sabah, Malaysia. In this area, C. polykrikoides has been reported to occur year-round with the highest cell density was $1.54 \times 10^{7}$ cells/L [9]. According to Richlen [12] the bloom of $C$. polykrikoides in the Arabian Gulf and Gulf of Oman, has caused mass killing of fish, damaging ecosystem of coral reefs, and impact the coastal tourism. In Korea, C. polykrikoides has bloom in the entire south coast of Korea and has 
caused US\$ 60 million economic losses [13]. The damage caused by $C$. polykrikoides not only affects the economy of the country but also decrease the trust of the consumer. Although C. polykrikodes is not a toxic species, the ability of this species to cause huge fish-killing in cage culture will bring fear to public on the safety of fish sell in the market. C. polykrikoides is a ichthytoxic dinoflagellate in which they can cause gill hyperglasia, hemorrhaging, squamation and apoptosis to fish gills and digestive tracts of fish [14][15].

The occurrence of $C$. polykrikoides has been reported to be supported by many factors. Study by Mohammad-Noor et al.[16] indicated that nutrient plays a significant role in triggering the bloom compared to physicochemical parameters. However, the right combination of nutrient and physicochemical parameters is needed to promote the bloom [16]. It is reported that C. polykrikoides occurred in their highest abundance when salinity range from 25-30 psu, temperature range from 29$30^{\circ} \mathrm{C}$ [15][9] and $\mathrm{pH}$ ranging from 8.1-8.7 [9]. The concentrations of nitrates and phosphate recorded in this study were low (Table 1) compared to nitrate and phosphate recorded during $C$. polykrikoides blooms in Kota Kinabalu, Sabah [17]. Regression analysis demonstrated no correlations between cell abundance and water quality parameters including nutrients. However, others studies reported that blooms of $C$. polykrikoides have positive correlation with ammonia, nitrates and phosphate. Koch [16], (2014), mentioned that this species prefer ammonium compared to urea and nitrate as nitrogen sources. The high flexibility in its nutrients acquisition strategies [14] give C. polykrikoides advantage to expand globally compared to other species.

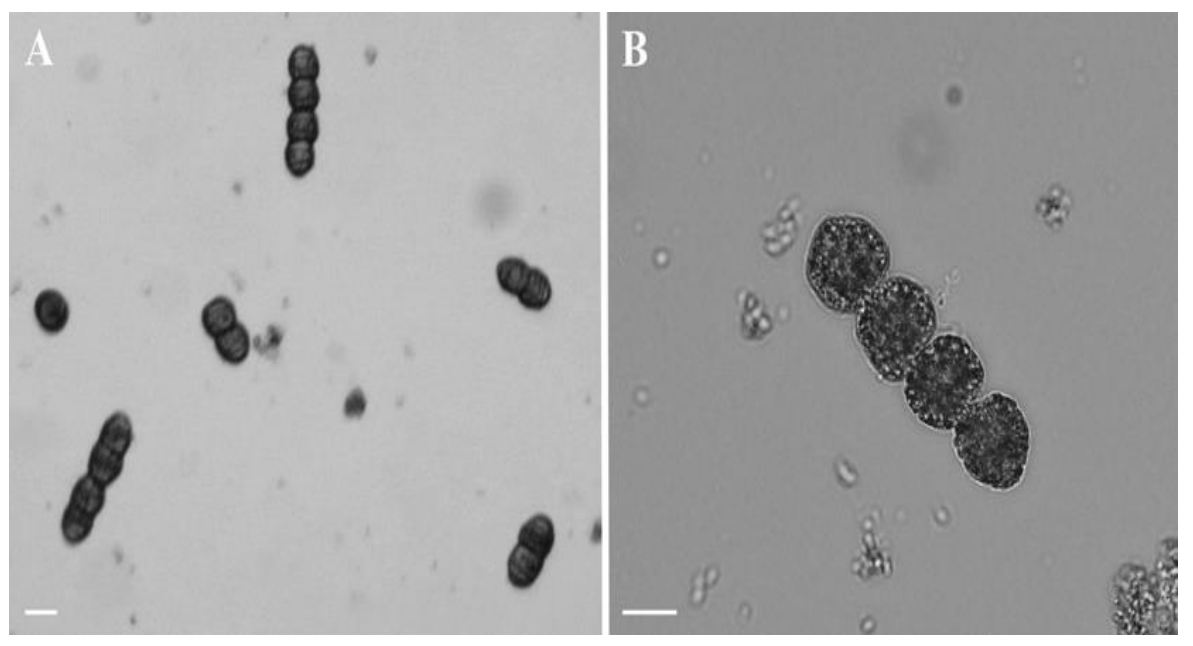

Figure 2. C. polykrikoides. A. Live samples from Perak coastal waters. B. Preserved samples from Straits of Tebrau. Scale bar $=20 \mu \mathrm{m}$.

Table 1. Mean with standard error of physico-chemical parameters and nutrients recorded at each location.

\begin{tabular}{lcc}
\hline & Johor & Perak \\
\hline $\mathrm{pH}$ & $7.68 \pm 0.09$ & $7.80 \pm 0.35$ \\
Salinity (psu) & $27.23 \pm 1.35$ & $28.03 \pm 4.33$ \\
Temperature ( $\square \mathrm{C})$ & $29.32 \pm 0.13$ & $30.9 \pm 0.50$ \\
Ammonia (mg/L) & $0.639 \pm 0.526$ & $0.321 \pm 0.193$ \\
Nitrate (mg/L) & $0.08 \pm 0.007$ & $0.094 \pm 0.002$ \\
Phosphate (mg/L) & $0.001 \pm 0.001$ & $0.00 \pm 0.000$ \\
\hline
\end{tabular}




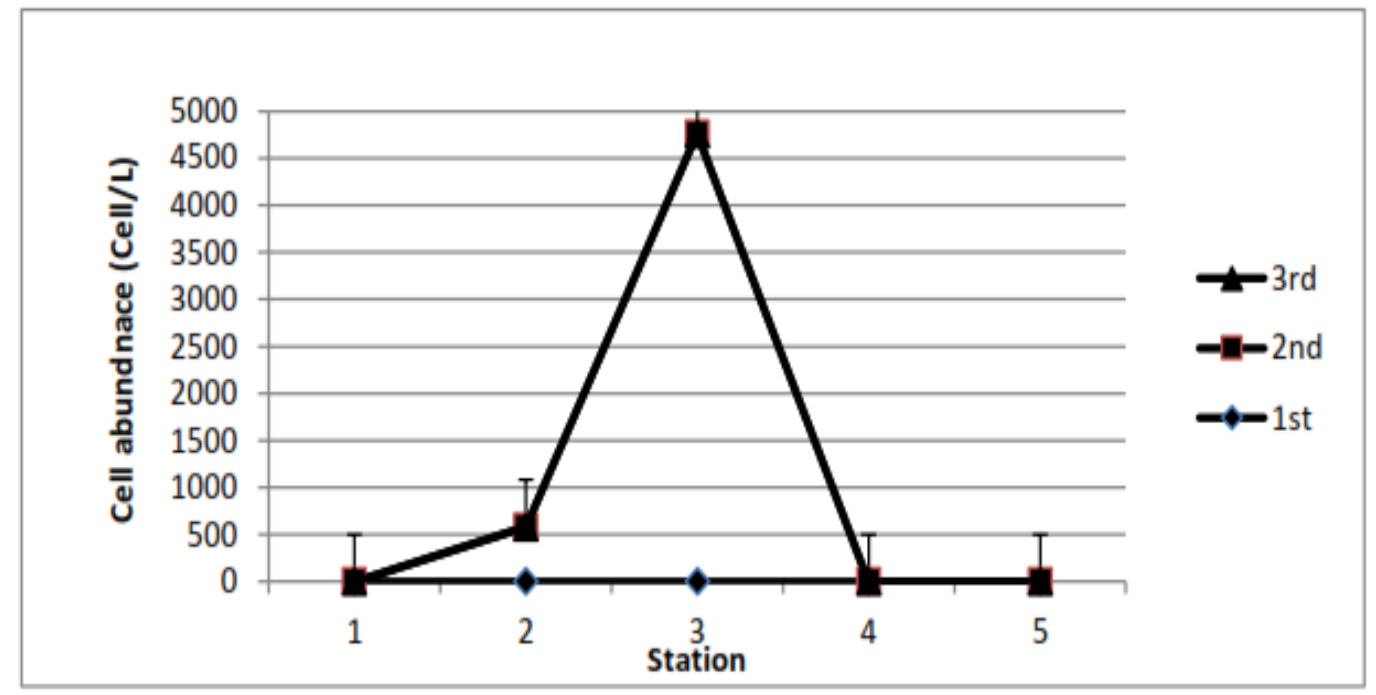

Figure 3. Cell abundance of C. polykrikoides in Perak coastal waters.

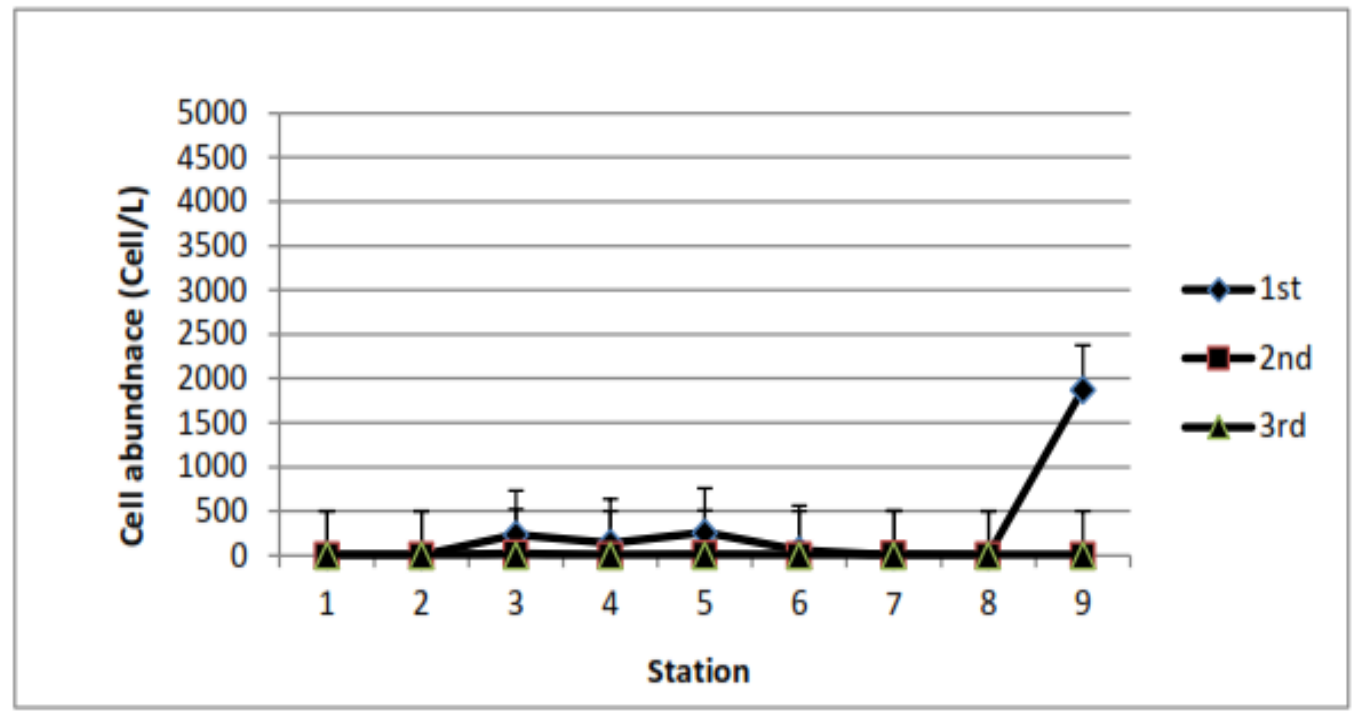

Figure 4. Cell abundance of C. polykrikoides in Straits of Tebrau

\section{CONCLUSIONS}

This is the first record of C. polykrikodes in Peninsular Malaysia. The occurrence creates an alarm to the respective authority to develop a management plan to control HAB in this area.

\section{ACKNOWLEDGEMENTS}

Special thanks are extended to staff of Institute of Oceanography and Maritime Studies (INOCEM), IIUM; Department of Marine Science, Kulliyyah of Science, IIUM and Fisheries Research Institute, Penang for their assistance during field sampling. This project is supported by grant FRGS 12-0920241 from Ministry of Higher Education awarded to NMN.

\section{REFERENCES}

1. Roy, R.N. (1977). Red tide and outbreak of paralytic shellfish poisoning in Sabah. Med. J. Malays. 31:247-251. 
2. Yuki, K. and Yoshimatsu, S. (1989). Twofish-killing species of Cochlodinium from Harima-Nada, Seto Inland Sea, Japan. In: Okaichi, T., Anderson, D., Nemoto, T. (Eds.). Red Tides: Biology, Environmental science and Toxicology. Elsevier, New Yok, pp. 451454.

3. Azanza, R.V., David, L.T., Borja, R.T., Baula, I.U. and Fukuyo, Y. (2008). An extensive Cochlodinium bloom along the western coast of Palawan, Philippines. Harmful Algae 7:324330

4. Kim, H. (1998). Harmful algal blooms in Korean coastal waters focused on three fish killing dinoflagellates. In: lee, H., Lee, S. Lee, C. (Eds.), Harmful algal blooms in Korea and China. NFRDI, Pusan, Korea.

5. Qi, D., Huang, Y., Wang, X. (19930. Toxic dinoflagellates red tide by a Cochlodinium sp. along the coast of Fujian, China. In: Smayda, T., Shimizu, Y. (Eds.), Toxic phytoplankton blooms in the sea. Elsevier, Amsterdam, pp. 235-238.

6. Tomas, C.R. and Smayda, T.J. (2008). Red tide blooms of Cochlodinium polykrikoides in a coastal cove. Harmful Algae. 7:308-317.

7. Iwataki, M., Kawami, H., Mizushima, K., Mikulski, C.M., Doucette, G.J., Relox Jr, J.R., Anton, A., Fukuyo, Y. and Matsuoka, K. (2008). Phylogenetic relationships in harmful dinoflagellate Cochlodinium polykrikoides (Gymnodiniales, Dinophyceae) inferred from LSU rDNA sequences. Harmful Algae 7:271277.

8. Anton, A., Teoh, P.L., Mohf-Shaleh, S.R. and Mohammad-Noor, N. (2008). First occurrence of Cochlodinium blooms in Sabah, Malaysia. Harmful Algae 7: 331-336.

9. Adam, A., Mohammad-Noor, N., Anton, A., Saleh, E., Shahbudin, A. and Sitti Raehanah, M.S. (2011). Temporal and spatial distribution of harmful algal bloom (HAB) species in coastal waters of Kota Kinabalu, Sabah, Malalysia. Harmful Algae 10:495-502.

10. Karlson, B., Godhe, A., Cusack, C. and Bres- nan, E. (2010). Introduction to methods for quantitative phytoplankton analysis. In: B, Karlson, C. Cusack and E. Bresnan (Eds.). Microscopic and molecular methods for quantitative phytoplankton analysis. UNESCO.

11. Parson, T.R., Maita, Y. and Lalli, C. M. (1984). A manual of chemical and biological methods for seawater analysis. Oxford, Pergamon Press.

12. Richlen, M.L., Morton, S.L., Jamali, E.A., Rajan, A., and Anderson, D.M. (2010). The Catastrophic 2008-2009 Red Tide in the Arabian Gulf Region, with Observations on the Identification and Phylogeny of the Fish-killing Dinoflagellate Cochlodinium polykrikoides. Harmful Algae 9:163-172

13. Kim, C.-J., Kim, H.-G., Kim, C.-H., and Oh, H.-M. (2007).Life Cycle of the Ichthyotoxin Dinoflagellate Cochlodinium polykrikoides in Korean Coastal Water.Harmful Algae 6: 104111.

14. Gobler, C.J., Berry, D.L., Anderson, O.R., Burson, A., Koch, F., Rodgers, B.S., Moore, L.K., Goleski, J.A., Allam, B., Bowser, P., Tang, Y. and Nuzzi, R. (2008). Characterization, dynamic and ecological impacts of harmful Cochlodinium polykrikoides blooms on eastern Long Island, NY, USA. Harmful Algae 7:293-307.

15. Kudela, R.M., and Gobler, C.J. (2012). Harmful Dinoflagellate Blooms caused by Cochlodinium sp.: Global Expansion and Ecological Strategies Facilitating Bloom Formation. Harmful Algae 14: 71-86

16. Mohammad-Noor, N., Weliyadi, E., Than, A., Adam, A and Hanan, D.S.M. (2014). Effects of meteorological conditions on the occurrence of Cochlodinium polykrikoides and Pyrodinium bahamense var. compressum in coastal waters of Kota Kinabalu, Sabah, Malaysia. Sains Malaysiana 43:21-29.

17. Koch, F., Burson, A., tang, Y.Z., Collier, J.L., Fisher, N.S., Sañudo-Wilhelmy, S. and Gobler, C.J. (2014). Alteration of plankton communities and biogeochemical cycles by harmful Cochlodinium polykrikoides (Dinophyceace) blooms. Harmful Algae 33:41-54. 